\title{
Hydration Characteristics of Coal-Fly Ash Containing High CaO Compound
}

\author{
Jun Soo Sim, Ki Gang Lee ${ }^{\dagger}$, Yu Taek Kim, and Seung Ku Kang \\ Department of Advanced Material Science and Engineering, Kyonggi University, Suwon 443-760, Korea \\ (Received February 29, 2012; Revised March 27, 2012; Accepted March 27, 2012)
}

\section{$\mathrm{CaO}$ 화합물이 다량 함유된 비산재의 수화 특성에 관한 연구 \\ 심준수 · 이기강 $\cdot$ 김유택 · 강승구 \\ 경기대학교 신소재공학과}

(2012년 2월 29일 접수 ; 2012년 3월 27일 수정 ; 2012년 3월 27일 채택)

\begin{abstract}
The purpose of this study was to examine a possibility that fly ash could be used as raw material for carbonation by conducting the experiment on magnetic separation and hydration of fly ash that contained a large amount of $\mathrm{CaO}$ composite. Wet magnetic separation experiment was performed to remove the component of magnetic substance that contained fly ash, which aimed at increasing the content of $\mathrm{CaO}$ in the non-magnetic domain. The selected fly ash was used for hydration experiment before the TGDTA, XRF and XRD analyses were made to confirm the Ca component that could be carbonated. Then, the fly ash was turned to a hydrate that was favorable to dissociation of $\mathrm{Ca}^{2+}$ ion. As a result, the magnetic separation enabled detecting the content of $\mathrm{CaO}$ component by up to $61 \mathrm{wt} \%$ in the non-magnetic domain. Since the hydrate was confirmed, it is believed that the fly ash can be used as raw material for carbonation.
\end{abstract}

\section{Keywords : Coal-ash, Fly ash, Hydration experiment, Magnetic separation, CCS(Carbon Capture \& Storage)}

\section{1. 서 론}

화력발전소에서 석탄을 이용하여 에너지를 생산하는 연 소방식에는 미분탄 연소방식과 순환유동층 연소방식이 있 다. 미분탄 연소방식은 다량의 석탄 연소와 신속한 자동 제어의 필요성 때문에 기존의 발전용 대형 보일러에서 가 장 많이 채용하고 있다. ${ }^{1)}$ 그러나 현재 전세계적으로 석탄 이 고갈되고 있으며, 이 가운데 유연탄과 같이 수분이 없 고 휘발량이 많은 고품위탄의 수급은 점점 어려워지고 있 는 실정이다. 유연탄보다 아래 단계인 아역청탄(subbituminous coal)의 경우 석탄 연소시간이 비교적 짧은 미분탄 연소방식에는 적합하지 않다. 이에 비해 순환유동층 연소 방식은 연료의 종류, 회분, 수분 함유량 등이 변해도 연 소에 미치는 영향이 적고, 미분탄 연소 등 기존 연소로에 는 적합하지 않는 고유황탄, 저품위탄, 폐기물 등 모든 가 연성 물질에 대하여 광범위한 연료 사용이 가능하다. ${ }^{1)}$ 또 한 연소로 온도를 약 $900^{\circ} \mathrm{C}$ 정도로 유지하여 질소산화물 생성을 억제할 수 있고, 석회석으로 노 내에서 집적 탈황

${ }^{\dagger}$ Corresponding author : Ki Gang Lee

E-mail : gglee@kyonggi.ac.kr

Tel : +82-31-249-9762 Fax : +82-31-244-6300
할 수도 있는 등의 장점 때문에 현재 순환유동층 연소 방 식의 화력발전소가 점점 증가하는 추세에 있다.

화력발전소에서 에너지를 생산하고 발생하는 발전부산 물인 석탄회는 크게 비산재 $(80 \%)$ 와 바닥재 $(20 \%)$ 로 구분 되는데, 미분탄 연소방식의 화력발전소에서 발생하는 비 산재의 경우 $80 \%$ 이상이 콘크리트 혼화재와 시멘트의 원 료로 활발히 사용되고 있다. ${ }^{2-4)}$ 이에 비해 순환유동층 연 소방식의 비산재의 경우 KS규격(KS L 5405)에 부합하지 못하여 콘크리트 혼화재와 시멘트의 원료로 사용되지 못 하고 전량 매립되고 있어 재활용이 시급히 요구되고 있다.

순환유동층 연소방식은 석회석을 이용하여 노 내 탈황 을 하기 때문에 발생된 비산재 내에는 $\mathrm{CaO}$ 화합물 성분 이 다량으로 함유되어 있어 이를 이용하여 탄산화 하는 방안으로 재활용이 가능하다고 판단된다. 국내의 경우 Lee 등 ${ }^{5}$ 이 석회석을 이용하여 수화 실험을 수행하여 탄산화 하는 실험을 하였고, Hong 등 ${ }^{6}$ 은 탄산나트륨을 이용하여 순환골재가 함유하고 있는 $\mathrm{Ca}(\mathrm{OH})_{2}$ 성분을 탄산화 하는 실험을 하였으나, 아직 비산재를 수화 실험을 수행하여 탄산화 가능 여부를 판단하는 실험의 사례는 크게 찾아 볼 수 없다. 비산재에 함유되어 있는 $\mathrm{CaO}$ 성분은 다른 화합물 형태로 존재하면 탄산화 반응을 일으키기 위한 $\mathrm{Ca}^{2+}$ 이온의 해리가 어렵기 때문에 탄산화에 유용하게 쓰 
일 수 없다. 따라서 비산재 내의 $\mathrm{CaO}$ 성분의 화합물 형 태가 탄산화 반응 기여도를 판단하는 기준이 되며, 이는 수화 실험을 수행하여 수화물 형태로 전환되는 여부를 확 인하여 판단이 가능하다. 비산재 내의 $\mathrm{CaO}$ 성분의 화합 물이 수화물로 전환된다면, 이는 탄산화 반응이 가능한 $\mathrm{Ca}^{2+}$ 이온의 해리가 유리하다는 것을 의미하며, $\mathrm{CCS}$ (Carbon Capture \& Storage)에 $\mathrm{Ca}^{2+}$ 이온을 수화물 형태로 용출시킨 뒤 탄산화 하는 방안이 반응속도 및 생성물의 분리에서 유 리할 수 있다는 연구가 보고 되었다.7) 또한 Choi 등)은 석 회석을 자력선별을 통해 불순물을 제거하여 $\mathrm{CaO}$ 의 백색 도를 높이는 실험을 하였고, Lee 등 ${ }^{9}$ 은 석탄 비산재를 자 력선별을 통해 철분을 회수하는 실험을 하였으나, 자력선 별을 통한 $\mathrm{CaO}$ 함유량의 변화에 대한 실험의 사례는 찾 아 볼 수 없었다.

따라서 본 실험에서는 다량의 $\mathrm{CaO}$ 성분을 함유하고 있 는 비산재를 자력선별을 통해 비산재 내 포함된 자성체 성분을 제거하여 비자성 구역에서의 $\mathrm{CaO}$ 함유량을 높여 탄산화에 기여하는 $\mathrm{Ca}$ 성분의 효율성을 높이고자 하였으 며, 수화 실험을 수행하여 $\mathrm{Ca}^{2+}$ 이온의 해리 정도를 규명 하여 수화물로 전환시켰을 때 탄산화 가능여부를 확인하 여 이를 통한 CCS 활용가능성에 대해 살펴보고자 한다.

\section{2. 실험 방법}

\section{1. 원료 분석}

본 실험에서 사용된 비산재의 화학조성을 $\mathrm{XRF}(\mathrm{ZSX}-$ $100 \mathrm{e}$, Rigaku, Japan)를 통해 분석한 결과를 Table 1에 나 타내었다. 화학적 주성분으로는 $\mathrm{CaO}$ 성분과 $\mathrm{SiO}_{2}$ 성분이 각각 $45.4 \%$ 와 $21.94 \%$ 이었다. 괄호 안은 강열감량을 제외 한 실질적인 $\mathrm{CaO}$ 성분의 함유량을 나타낸 것이다. $\mathrm{CaO}$ 성분의 함유량이 많은 것은 노 내 탈황을 위해 석회석을 참가하였기 때문이며, $\mathrm{SO}_{3}$ 성분의 함유량은 $4.25 \mathrm{wt} \%$ 이므 로 $\mathrm{CaSO}_{4}$ 로 환산할 때 필요한 $\mathrm{CaO}$ 의 양은 약 $2.88 \mathrm{wt} \%$ 이기 때문에 비산재 내에는 약 $42 \mathrm{wt} \%$ 의 잉여의 $\mathrm{CaO}$ 화 합물이 존재할 것으로 판단되며, 이는 XRF 화학조성 분 석 결과를 통해 확인할 수 있었다.

\section{2. 자력 선별}

자성에 대한 차이를 이용하여 $\mathrm{CaO}$ 성분의 분리선별 가 능성을 확인하고자 비산재를 자력선별 하였다. 비산재는 미립자로 되어 있어 건식 자력선별시 정전기력이 발생하
여 자성과 비자성에 의한 차이를 이용할 수 없어 습식 자 력선별을 통해 분리선별 하였다. 습식 자력선별은 비산재 와 증류수를 혼합하여 고액비(무게비) $1: 10$ 의 용액을 제 조하였으며, 제조된 용액에 자력을 이용하여 분리선별하 였다. 자력은 2000 10000 가우스까지 2000 가우스 별로 변화시키면서 실험을 수행하였다. 선별된 비산재는 $105^{\circ} \mathrm{C}$ 에서 24시간동안 건조시킨 후 건조된 시료의 무게를 측 정하여 각 가우스별 분리율을 측정하였고, $\mathrm{XRF}$ 화학조성 분석을 통해 자력선별이 비산재의 화학조성에 미치는 영 향에 대해 분석하였다.

\section{3. 수화 실험}

수화 실험은 탄산화 가능여부를 판단하기 위해 수행되었 으며, 비산재와 증류수를 혼합- 밀봉하여 $40^{\circ} \mathrm{C}$ 항온조에서 7 일간 양생하였다. 수화된 비산재는 아세톤에 24시간 동안 담가 수화정지를 시키고, 필터 페이퍼를 이용하여 고체 시 료를 걸러내어 $40^{\circ} \mathrm{C}$ 항온조에서 24 시간 동안 충분히 건조 하였다. 건조된 시료는 미분으로 분쇄하여 TG-DTA(STA $409 \mathrm{C} / \mathrm{CD}$, Netzsch. Co., Ger.) 분석을 통해 수화물의 열적 특성을 분석하였고, X-선 회절 분석(XRD, RINT- $8100 \mathrm{H} / \mathrm{PC}$, Rigaku, Japan)을 통해 결정상 분석을 하였다.

\section{3. 결과 및 고찰}

\section{1. 비산재의 물리적, 화학적 성질}

본 실험에서 사용된 비산재는 전기 집진기로 포획한 것 으로 Fig. 1에 나타낸 바와 같이 매우 미세하고 좁은 입

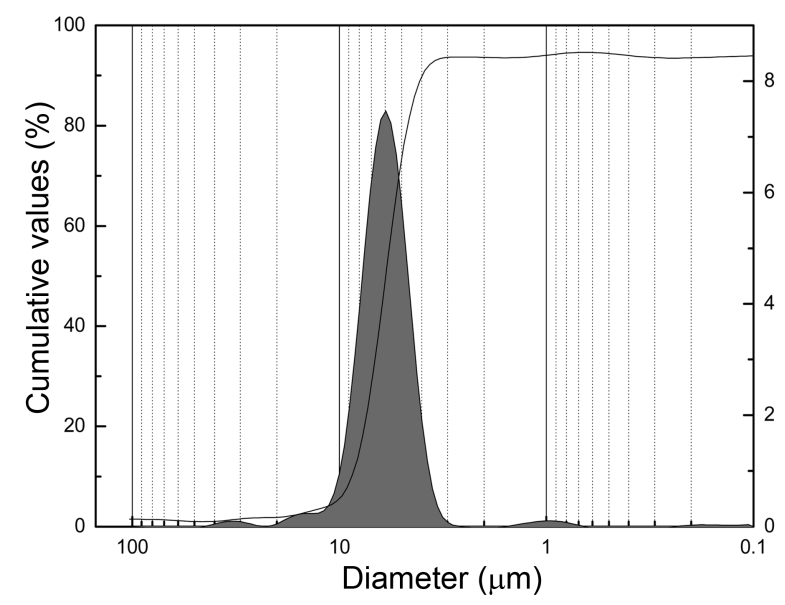

Fig. 1. Particle size distribution for F/A.

Table 1. Chemical Compositions of Fly Ash(wt\%)

\begin{tabular}{|c|c|c|c|c|c|c|c|c|c|c|c|c|}
\hline \multirow{2}{*}{$\mathrm{F} / \mathrm{A}^{*}$} & $\mathrm{SiO}_{2}$ & $\mathrm{Al}_{2} \mathrm{O}_{3}$ & $\mathrm{Fe}_{2} \mathrm{O}_{3}$ & $\mathrm{CaO}$ & $\mathrm{MgO}$ & $\mathrm{Na}_{2} \mathrm{O}$ & $\mathrm{K}_{2} \mathrm{O}$ & $\mathrm{TiO}_{2}$ & $\mathrm{P}_{2} \mathrm{O}_{5}$ & $\mathrm{SO}_{3}$ & Ig. loss & Total \\
\hline & 21.94 & 8.53 & 6.05 & $45.4(48.3)$ & 6.06 & 0.06 & 0.48 & 0.5 & 0.08 & 4.25 & 6.65 & 100.0 \\
\hline
\end{tabular}

*F/A : Fly Ash

( ) : Except Ig.loss

한국세라믹학회지 


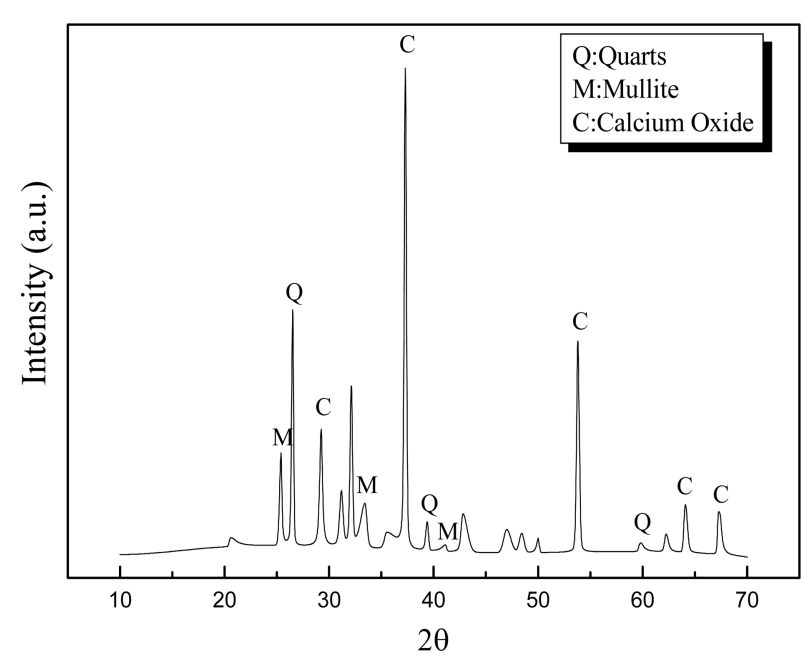

Fig. 2. XRD Analysis of F/A.

도분포를 가지며 평균입경 약 $6 \mu \mathrm{m}$ 의 입경을 갖는다. 비 산재의 결정상을 $\mathrm{XRD}$ 로 분석한 결과를 Fig. 2에 나타내 었다. 주 결정상으로는 Calcium Oxide $(\mathrm{CaO})$ 와 Quarts $\left(\mathrm{SiO}_{2}\right)$, Mullite $\left(2 \mathrm{SiO}_{2} 3 \mathrm{Al}_{2} \mathrm{O}_{3}\right)$ 로 나타났다. 일반적인 비산 재에서 발생하는 결정상과 비슷한 경향을 나타내고 있으 나, $\mathrm{CaO}$ 성분의 피크가 일반적인 비산재 보다 크게 관찰 되는 것을 확인 할 수 있다. 이는 발전소별로 사용되는 석탄의 종류와 운전조건 차이에 의한 것으로 판단되며, 순환유동층 보일러 연소방식을 사용하는 화력발전소의 경 우 석탄 연소 과정 중 발생하는 황 성분을 제거하기 위 해 노 내에 석회석을 첨가하여 탈황하기 때문에 XRD 분 석 결과 나타난 $\mathrm{CaO}$ 성분의 피크는 탈황 공정에서 황 성 분과 결합되지 않은 석회 성분이 잔재하여 비산재 내에 함유된 것으로 사료된다.

\section{2. 습식 자력선별을 이용한 비산재의 선별 분리}

화력발전소의 보일러에서 석탄의 연소 과정을 통해 발 생하는 석탄회는 아래와 같은 반응이 일어난다.

$$
\begin{aligned}
& \mathrm{C}+\mathrm{O}_{2} \rightarrow \mathrm{CO}_{2} \\
& 2 \mathrm{C}+\mathrm{O}_{2} \rightarrow 2 \mathrm{CO}\left(\mathrm{Over} 700^{\circ} \mathrm{C}\right) \\
& 3 \mathrm{Fe}_{2} \mathrm{O}_{3} \rightarrow 2 \mathrm{FeO} \cdot \mathrm{Fe}_{2} \mathrm{O}_{3}+1 / 2 \mathrm{O}_{2} \text { (at Pco atmosphere) }
\end{aligned}
$$

이러한 과정에서 약자성체 $\left(\mathrm{Fe}_{2} \mathrm{O}_{3}\right)$ 는 강자성체인 Spinel 구조 $\left(\mathrm{FeO} \cdot \mathrm{Fe}_{2} \mathrm{O}_{3}\right)$ 로 전환되며, 석탄 연소 과정 후 발생된 석탄회는 $\mathrm{FeO} \cdot \mathrm{Fe}_{2} \mathrm{O}_{3}$ 뿐만 아니라 그밖에 자성체 성분을 함유하고 있어 자력을 이용한 분리가 가능하다. 따라서 자력선별을 이용하여 비산재 내 함유된 자성체 성분을 제 거하여 비자성 구역에서의 $\mathrm{CaO}$ 성분의 함유량 변화를 알 아보고자 비산재와 증류수를 고액비(무게비) $1: 10$ 의 용 액을 제조하여 습식 자력선별 실험을 수행하였다. 제조된 용액은 자력을 이용하여 선별 실험을 수행하였고, 자력은
Table 2. Separation rate for F/A after Magnetic Separation(solid/ liquid $=0.1$ )

\begin{tabular}{ccc}
\hline Gauss & Magnetism & Separation rate(\%) \\
\hline \multirow{2}{*}{2000} & $\mathrm{M}^{*}$ & 30 \\
& $\mathrm{NM}^{*}$ & 70 \\
4000 & $\mathrm{M}$ & 40 \\
& $\mathrm{NM}$ & 60 \\
6000 & $\mathrm{M}$ & 77 \\
& $\mathrm{NM}$ & 23 \\
8000 & $\mathrm{M}$ & 81 \\
& $\mathrm{NM}$ & 19 \\
10000 & $\mathrm{M}$ & 89 \\
& $\mathrm{NM}$ & 11 \\
\hline *M $:$ Magnetic domain & NM $\mathrm{Non}$ Magnetic domain
\end{tabular}

*M : Magnetic domain, $\mathrm{NM}$ : Non Magnetic domain

2000 10000 가우스까지 2000 가우스별로 변화시켰다. 선 별 분리된 시료는 건조 후 무게를 측정하여 자력 변화에 따른 분리율을 측정하였으며, 그 결과를 Table 2에 나타 내었다. 자력이 증가할수록 자성 구역에서의 분리율은 $30 \%$ 에서 $89 \%$ 까지 증가하는 것을 확인할 수 있었으며, 이 는 자력이 증가할수록 비산재 내 자성 세기가 비교적 작 은 광물들도 선별되어 분리율이 증가한 것으로 사료된다. Table 3은 자력 변화에 따른 비산재의 XRF 화학조성 분 석 결과이다. 분석 결과 각 가우스별 비자성 구역과 자성 구역의 $\mathrm{CaO}$ 성분과 $\mathrm{Fe}_{2} \mathrm{O}_{3}$ 성분의 화학 조성이 큰 차이를 보이고 있었으며, 자력선별이 기타 미량 성분의 화학 조 성에 미치는 영향은 거의 없는 것으로 확인 되었다. 이는 자력선별을 통한 비산재 내 함유된 자성체 성분이 분리 되어 자성 구역에서의 $\mathrm{Fe}_{2} \mathrm{O}_{3}$ 성분의 함유량은 증가하며, 비자성 구역에서의 $\mathrm{CaO}$ 성분은 자성 구역과 비교 시 상 대적 함유량이 증가함을 확인할 수 있었다. 또한 8000 가 우스 이상의 자력에서의 $\mathrm{CaO}$ 성분의 함유량은 약 $45 \sim 48 \%$ 로 나타났으며, 강열감량을 제외한 실직적인 $\mathrm{CaO}$ 성분의 함유량은 약 57 61\%로써 이는 원료보다 약 9 13\% 증가 하였음을 알 수 있었다. 따라서 자력선별을 통해 자성체 성분을 제거하여 비자성 구역의 $\mathrm{CaO}$ 성분을 효과적으로 농축시킬 수 있음을 확인할 수 있었다.

\section{3. 비산재의 수화 특성에 관한 고찰}

Fig. 3 은 수화 실험 수행 후 비산재의 수화물 전환 여 부를 확인하기 위하여 $\mathrm{XRD}$ 로 결정상을 분석한 결과이다. 수화물로 전환되었다는 것은 탄산화에 기여할 수 $\mathrm{Ca}^{2+}$ 이 온의 해리가 유리하다는 것을 의미한다. 분석 결과 비산 재의 원료에서 확인되었던 $\mathrm{CaO}$ 성분의 피크는 확인되지 않았으며, 수화물인 $\mathrm{Ca}(\mathrm{OH})_{2}$ 의 피크가 나타나는 것으로 보아 이는 비산재가 함유한 $\mathrm{CaO}$ 성분이 $\mathrm{H}_{2} \mathrm{O}$ 와 반응하여 수화물인 $\mathrm{Ca}(\mathrm{OH})_{2}$ 로 전환하였음을 알 수 있다. 비산재 원 
Table 3. Chemical Composition of F/A after Magnetic Separation (wt $\%$ )

\begin{tabular}{|c|c|c|c|c|c|c|c|c|c|c|c|c|c|}
\hline & & $\mathrm{SiO}_{2}$ & $\mathrm{Al}_{2} \mathrm{O}_{3}$ & $\mathrm{Fe}_{2} \mathrm{O}_{3}$ & $\mathrm{CaO}$ & $\mathrm{MgO}$ & $\mathrm{Na}_{2} \mathrm{O}$ & $\mathrm{K}_{2} \mathrm{O}$ & $\mathrm{TiO}_{2}$ & $\mathrm{P}_{2} \mathrm{O}_{5}$ & $\mathrm{SO}_{3}$ & Ig. loss & Total \\
\hline Hydrated & $\mathrm{F} / \mathrm{A}$ & 18.70 & 8.80 & 5.33 & $39.46(48.81)$ & 5.29 & 0.05 & 0.49 & 0.40 & 0.06 & 3.73 & 17.69 & 100.0 \\
\hline \multirow{2}{*}{$2000 \mathrm{G}$} & M & 23.61 & 9.53 & 13.13 & $34.00(37.61)$ & 5.95 & 0.09 & 0.51 & 0.61 & 0.09 & 2.93 & 9.56 & 100.0 \\
\hline & NM & 18.46 & 6.96 & 4.84 & $39.92(50.29)$ & 5.07 & 0.06 & 0.38 & 0.42 & 0.07 & 3.33 & 20.49 & 100.0 \\
\hline \multirow{2}{*}{$4000 \mathrm{G}$} & M & 25.2 & 10.2 & 10.31 & $34.23(38.35)$ & 5.91 & 0.11 & 0.57 & 0.65 & 0.09 & 2.14 & 10.59 & 100.0 \\
\hline & NM & 19.08 & 7.07 & 4.6 & $42.53(51.62)$ & 5.34 & 0.08 & 0.41 & 0.43 & 0.07 & 2.91 & 17.48 & 100.0 \\
\hline \multirow{2}{*}{$6000 \mathrm{G}$} & M & 22.91 & 9.16 & 7.89 & $36.89(42.94)$ & 5.51 & 0.06 & 0.62 & 0.51 & 0.08 & 2.28 & 14.09 & 100.0 \\
\hline & NM & 16.96 & 6.53 & 4.24 & $44.10(54.54)$ & 4.93 & 0.02 & 0.40 & 0.36 & 0.06 & 3.26 & 19.14 & 100.0 \\
\hline \multirow{2}{*}{$8000 \mathrm{G}$} & M & 21.71 & 8.60 & 6.69 & $37.48(44.90)$ & 5.26 & 0.06 & 0.55 & 0.48 & 0.07 & 2.58 & 16.52 & 100.0 \\
\hline & NM & 13.15 & 4.99 & 3.07 & $48.01(60.71)$ & 4.83 & 0.01 & 0.32 & 0.27 & 0.06 & 4.32 & 20.97 & 100.0 \\
\hline \multirow{2}{*}{$10000 \mathrm{G}$} & M & 24.57 & 9.63 & 8.40 & $35.70(43.95)$ & 5.80 & 0.09 & 0.54 & 0.60 & 0.09 & 2.79 & 11.79 & 100.0 \\
\hline & NM & 16.6 & 6.20 & 3.82 & $44.67(57.20)$ & 5.17 & 0.05 & 0.34 & 0.38 & 0.06 & 3.82 & 18.89 & 100.0 \\
\hline
\end{tabular}

( ) : Except Ig.loss

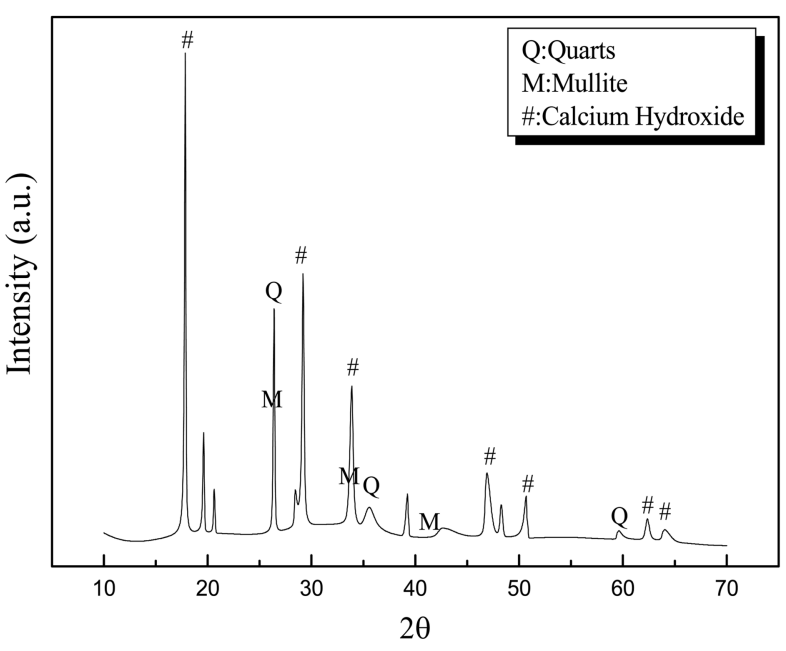

Fig. 3. XRD Analysis of Hydrated F/A.

료와 수화된 비산재의 열적 특성을 TG-DTA로 분석한 결 과를 각각 Fig. 4(a)와 (b)에 나타내었다. Fig. 4(a)와 (b) 그래프 모두 $450 \sim 500^{\circ} \mathrm{C}$ 부근과 $800^{\circ} \mathrm{C}$ 부근에서 흡열반응 과 동시에 무게감량을 나타내고 있다. $450 \sim 500^{\circ} \mathrm{C}$ 부근에 서의 흡열반응과 무게감량은 $\mathrm{Ca}(\mathrm{OH})_{2}$ 가 열분해에 의해 $\mathrm{CaO}$ 와 $\mathrm{H}_{2} \mathrm{O}$ 로 분해되면서 감량이 나타난 것으로써 비산 재 원료의 경우 약 $2.7 \%$ 의 무게감량을 나타내었고, 수화 된 비산재는 약 $9.3 \%$ 의 무게감량을 나타내었다. 이는 수 화물로 전환 가능한 $\mathrm{CaO}$ 성분이 수화물로 전환되었음을 의미하며, 이를 통해 탄산화 가능한 원료로서의 가능성을 보이고 있음을 알 수 있다. $800^{\circ} \mathrm{C}$ 부근에서의 흡열반응과 무게감량은 원료 내 일부 함유되어 있는 $\mathrm{CaCO}_{3}$ 에서 $\mathrm{CO}_{2}$ 의 탈착에 의한 감량으로 판단되며 수화된 비산재에서 감 량이 더 크게 나타난 것은 수화실험 과정에서 해리된 $\mathrm{Ca}^{2+}$ 이온이 대기 중에 존재하는 $\mathrm{CO}_{2}$ 와 반응하여 $\mathrm{CaCO}_{3}$ 로 전 환되어 원료보다 더 크게 감량이 나타난 것으로 사료된

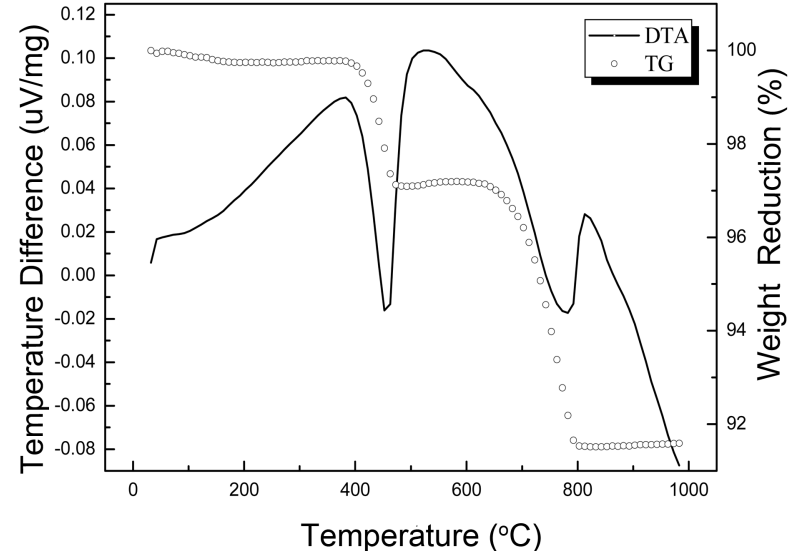

(a)

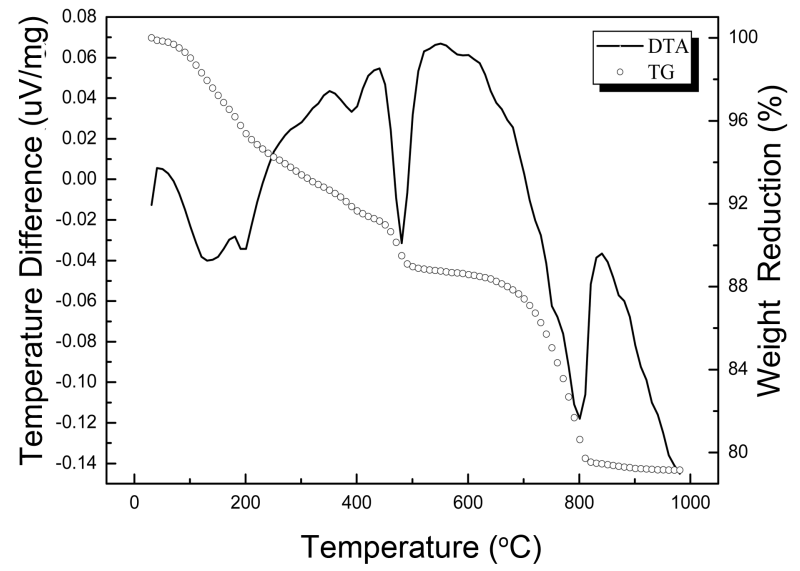

(b)

Fig. 4. TG-DTA Analysis of (a) F/A and (b) Hydrated F/A.

다. 또한 Table 3의 분석 결과에서도 알 수 있듯이 수화 된 비산재의 강열감량은 약 $17.7 \mathrm{wt} \%$ 이고, 자성 구역의 강열감량은 9.56 16.52 wt\%로써 수화된 비산재보다 작은 


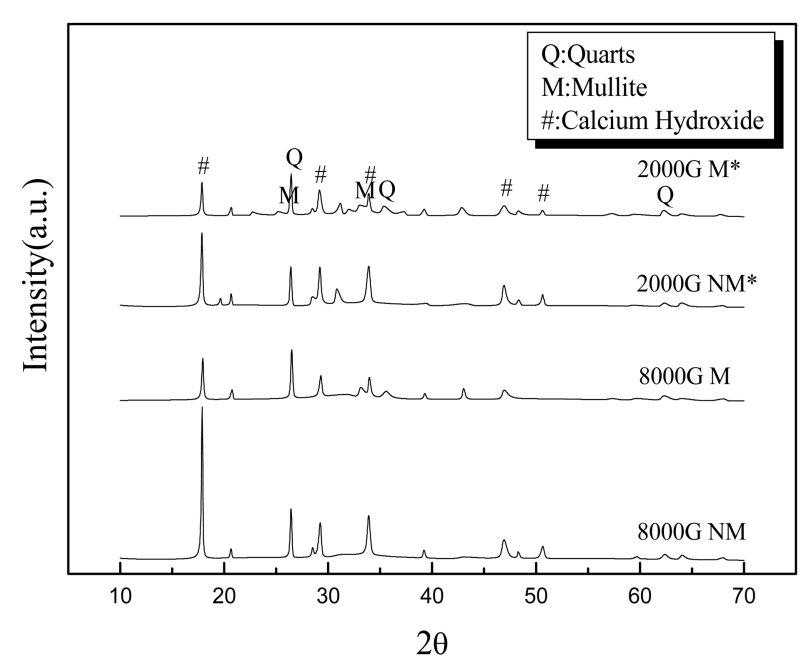

Fig. 5. XRD Analysis of Hydrated F/A after each Magnetic Separation $\left(* \mathrm{M}:\right.$ Magnetic domain, ${ }^{*} \mathrm{NM}$ : Non Magnetic domain).

감량을 나타내고 있다. 이는 자성 구역의 $\mathrm{CaO}$ 성분은 탄 산화에 유리한 원료가 아닌 것으로 사료되며, 이에 반해 비자성 구역의 강열감량은 $18.89 \sim 20.97 \mathrm{wt} \%$ 로써 이는 비 자성 구역에서 수화물로 전환할 수 있는 $\mathrm{CaO}$ 성분의 함 유량이 더 많은 것을 의미하며 탄산화에 유리한 원료로 사용할 수 있을 것으로 판단된다.

2000 가우스와 8000 가우스의 분리 선별된 비산재를 수 화 실험을 수행하여 건조한 시료를 $\mathrm{XRD}$ 로 결정상 분석 한 결과를 Fig. 5에 나타내었다. Fig. 5의 그래프에서 알 수 있듯이 주 결정상으로 calcium hydroxide $\left(\mathrm{Ca}(\mathrm{OH})_{2}\right)$ 의 피크와 quartz $\left(\mathrm{SiO}_{2}\right)$ 의 피크가 나타나는 것을 확인할 수 있으며, 자성 구역보다 비자성 구역의 $\mathrm{Ca}(\mathrm{OH})_{2}$ 피크가 크 게 나타나는 것을 알 수 있었다. 또한 2000 가우스 보다 8000 가우스의 비자성 구역의 $\mathrm{Ca}(\mathrm{OH})_{2}$ 피크가 더 크게 나타났으며, 이는 가우스가 증가할수록 제거되는 자성체 성분이 증가하였기 때문이다. 이를 통해 비자성 구역에서 의 $\mathrm{Ca}$ 성분의 함유량이 더 많다는 것을 알 수 있으며, 자 력이 증가할수록 $\mathrm{Ca}$ 성분을 효과적으로 농축시킬 수 있 음을 확인할 수 있었다. 8000 가우스에서의 자성 구역과 비자성 구역의 비산재를 각각 수화 실험을 수행하여 TGDTA 분석한 결과를 Fig. 6(a)와 (b)에 나타내었다. Fig. 6(a) 와 (b) 그래프 모두 $450 \sim 500^{\circ} \mathrm{C}$ 부근과 $800^{\circ} \mathrm{C}$ 부근에서 흡 열반응과 동시에 무게감량을 나타내고 있는 것으로 보아 Fig. 4의 그래프와 비슷한 경향을 나타내고 있음을 확인할 수 있었다. 8000 가우스 자성 구역의 수화된 비산재는 $450 \sim 500^{\circ} \mathrm{C}$ 부근에서의 약 $6.55 \%$ 의 무게감량을 나타내었 고, 비자성 구역의 수화된 비산재는 약 $13.65 \%$ 의 무게감 량을 나타내었으며, 이는 자력선별로 비자성 구역의 비산 재가 자성 구역의 비산재보다 약 2 배에 달하는 탄산화 능 력이 있다고 사료된다.

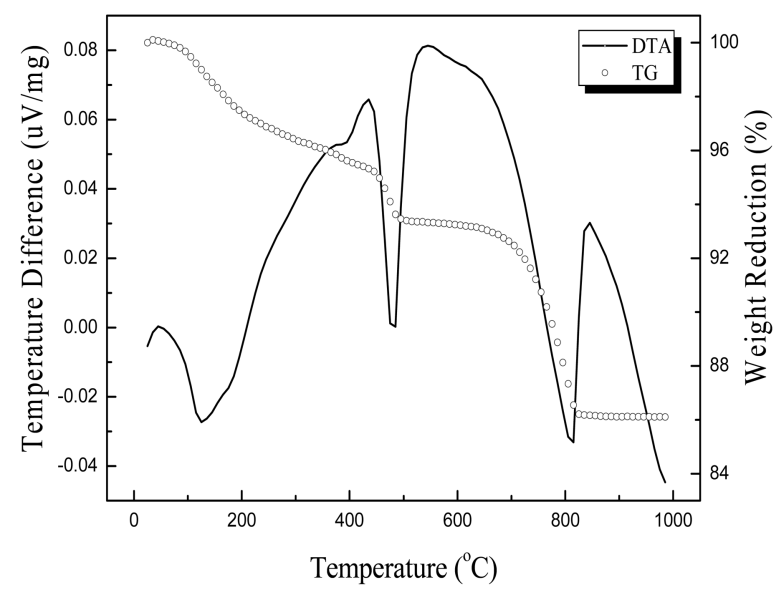

(a)

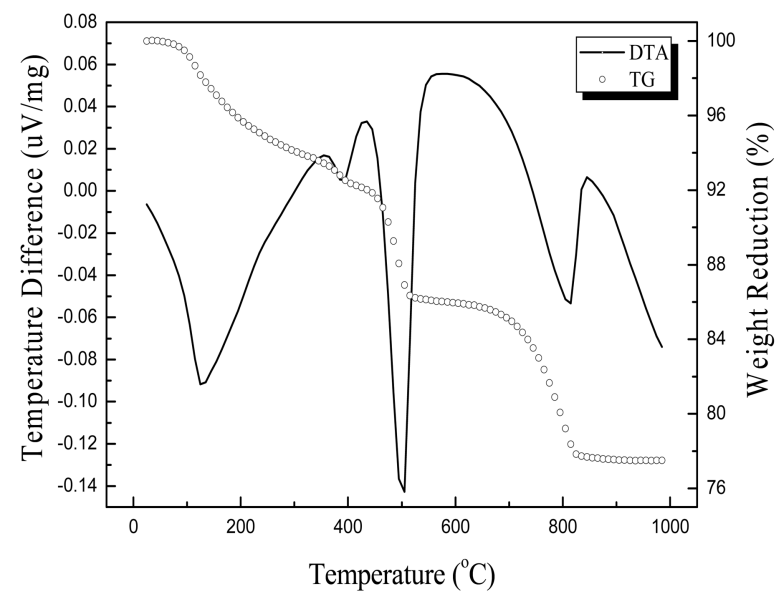

(b)

Fig. 6. TG-DTA Analysis of Hydrated F/A after Magnetic Separation at $8000 \mathrm{G}$ (a) Magnetic domain and (b) Non-Magnetic domain.

\section{4. 결 론}

1) 본 실험에서 사용한 비산재는 평균입경 $6 \mu \mathrm{m}$ 의 입 경을 가지며 화학조성 분석 결과, 다량의 $\mathrm{CaO}$ 성분을 함 유하고 있었다. 이는 순환유동층 보일러 연소 방식의 발 전소에서 석탄 연소 과정에서 발생하는 황을 제거하기 위 해 첨가한 석회 성분이 잔재한 것으로 판단된다.

2) 습식 자력선별을 통해 자성체 성분을 제거하여 비자 성 구역에서 $\mathrm{CaO}$ 성분의 함유량이 증가함을 알 수 있었 으며, 또한 자력이 증가할수록 비자성 구역의 $\mathrm{CaO}$ 성분 의 함유량은 증가하였다. 8000 가우스 이상의 자력에서 $\mathrm{CaO}$ 성분의 함유량을 약 $48 \%$ 까지 농축시킬 수 있었고, 강열감량을 제외한 실직적인 $\mathrm{CaO}$ 성분의 함유량은 약 $61 \%$ 로써 원료보다 약 9 13\% 효과적으로 농축시킬 수 있 음을 확인하였다.

3) 수화 실험 결과, 비산재가 함유한 다량의 $\mathrm{CaO}$ 성분 
이 $\mathrm{Ca}(\mathrm{OH})_{2}$ 로 전환되었으며, 전환된 $\mathrm{Ca}$ 계 수화물은 탄산 화에 기여할 수 있는 $\mathrm{Ca}^{2+}$ 이온의 해리가 유리하므로 이 를 이용하여 탄산화 원료로 사용 가능할 것으로 판단된 다. 또한 TG-DTA 결과로 보아 비자성 구역의 비산재가 자성 구역의 비산재보다 약 2 배에 달하는 탄산화 능력이 있다고 사료된다.

\section{Acknowledgment}

본 연구는 한국남부발전(주)의 지원에 의하여 기초전력 연구원(과제관리번호 11108)주관으로 수행된 과제이며, 이 에 감사드립니다.

\section{REFERENCES}

1. E. D. Jeong and S. J. Moon, "Co-combustion Characteristics of Mixed Coal with Anthracite and Bituminous in a Circulating Fluidized Bed Boiler," J. Plant., 6 [1] 70-77 (2010).

2. B. S. Chun and Y. H. Yeoh, "A Study on the Recycling of Coal Ash as Structural Backfill Materials," J. Kor. Soc. Ocean Eng., 14 [1] 74-79 (2000).
3. S. J. Choi and M. H. Kim, "A Study on the Durabilities of High Volume Coal Ash Concrete by the Kinds of Coal Ash," J. Kor. Insti. Build. Const., 9 [3] 73-8 (2009).

4. Y. W. Yoon, K. S. Chae, and K. H. Song, "Evaluation of Static and Dynamic Characteristic of Coal Ashes," J. Kor. Geo-Enciron. Soc., 10 [3] 5-12 (2009).

5. J. J. Lee and J. L. Park, "Manufacture of Precipitated Calcium Carbonate from Pungchon Limestone," J. Ind. Tech. Kangwon Nat'l Univ., 21 [A] 253-59 (2001).

6. S. R. Hong, H. S. Kim, E. G. Kwak, S. G. Park, and J. M. Kim, "Characteristics of Recycled Fine Aggregate by Sodium Carbonated Water," J. Kor. Recy. Const. Res. Insti., 6 [2] 97-102 (2011).

7. K. S. Lackner, D. P. Butt, and C. H. Wendt, "Progress on Binding $\mathrm{CO}_{2}$ in Mineral Substrates," Energy Convers. Mgmt., 38 (supplement 1), 259-64 (1997).

8. J. S. Choi and C. H. Park, "Study on Whiteness Improvement of Precipitated Calcium Carbonate Made from Jeongseon Limestone in Korea," J. Kor. Insti. Mineral. \& Ener. Eng., 36 [6] 456-62 (1999).

9. H. G. Lee and C. T. Lee, "Recovery of Fe Fraction from Coal Fly Ash by Using High Gradient Magnetic Separator," $J$. Kor. Ind. \& Eng. Chem., 6 [4] $601-9$ (1995). 